\title{
Vegetable Cultivation: An Alternative Horticultural Farming in Kurnool District, Andhra Pradesh
}

\author{
Kanthi Kiran, K ${ }^{1}$ Krishna Kumari, A ${ }^{2}$ \\ ${ }^{1}$ Research Scholar, 2 Professor of Geography \\ 1,2Sri Krishnadevaraya University, Anantapur, Andhra Pradesh, India
}

\begin{abstract}
How to cite this paper: Kanthi Kiran, $\mathrm{K} \mid$ Krishna Kumari, A "Vegetable Cultivation: An Alternative Horticultural Farming in Kurnool District, Andhra Pradesh" Published in International Journal of Trend in Scientific Research and Development (ijtsrd), ISSN: 24566470, Volume-3 | Issue-4, June 2019, pp.998-1002, URL: https://www.ijtsrd.c om/papers/ijtsrd23 980.pdf

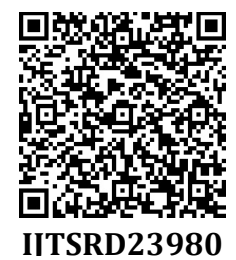

Copyright (C) 2019 by author(s) and International Journal of Trend in Scientific Research and Development Journal. This is an Open Access article distributed under the terms of the Creative Commons

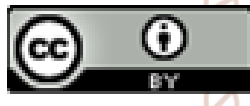
Attribution License (CC BY 4.0) (http://creativecommons.org/licenses/ by/4.0)

\section{ABSTRACT}

In India nearly about 10.1 million hectares of area is under vegetable farming. The country is the largest producer of ginger and okra amongst vegetables and ranks second in the production of Potatoes, Onions, Cauliflower, Brinjal, Cabbage etc. India's diverse climate ensures availability of a variety of vegetables. As per National Horticulture Board, during 2015-16, India produced 169.1 million metric tonnes of vegetables. The vast production base offers India, tremendous opportunities for the export. During 2017-18 India exported fruits and vegetables worth Rs. 9410.81 crores in which vegetables comprised of Rs 5181.78 crores. Keeping the importance of vegetable farming in view, an endeavour is made here to study the spatial patterns of vegetable crop cultivation in Kurnool District, Andhra Pradesh.

Keywords: Vegetable crops, Spatial Patterns, Horticultural farming

\section{INTRODUCTION}

Horticulture is the branch of agriculture, which deals with the cultivation of fruits, vegetables, flowers, spices \& condiments, plantation crops, Tuber crops and Medicinal \& Aromatic plants. Through India's horticultural products share in the global market is $1 \%$, there is increasing acceptance of horticulture produce from the country. This has occurred due to concurrent developments in the areas of state of the art cold chain infrastructure and quality assurance measures. Apart from the large investment pumped in by the private sector ,Public sector has also taken initiatives and with APEDA's assistance several centres for perishable cargoes and integrated post-harvest handling facilities have been set up in the country. Capacity building initiatives at the farmers, processors and exporters levels has also contributed towards this effort.
Andhra Pradesh state with high geographical diversity, different agro climatic zones, varied soil types and good irrigation resources is better placed for production of various horticultural crops. Horticulture contributes to approximately 4 percent of united Andhra Pradesh GSDP. They cover 12 percent of the gross cropped area accounting for 16 lakh hectares with an annual production of 118 lakh tonnes. United Andhra Pradesh rank first in the production of Mango, Chillies, Turmaric, Sweet lime and Papaya in the country.

Kurnool district is having an important place in the map of state's horticultural crops production. It is one of the major producers of Tomato, Bhendi and Onions. Hence identifying the growing demand and importance of vegetable crops, an attempt on spatial patterns of vegetable crops has been taken up in this article.

\section{Objectives:}

- To study the spatial patterns of Horticultural crops in Kurnool district.

- To study the spatial distributing of vegetable crop farming in the district.
Methodology \& Techniques used:

To fulfil the set objectives, secondary data regarding to horticultural crops in particular and vegetable crops in general for the year 2010-11 have been used for the analysis. All the secondary data has been collected from District Statistical Bureau and planning office, Kurnool. Simple statistical techniques such as averages, percentages etc have been applied using SPSS package. GIS software is used to map the required data.

\section{Study Area:}

Kurnool district is the second largest district of separated Andhra Pradesh state occupying 17,658 sq kms of area, which account for 11.02 percent of the total geographical area of the state. It lies between the northern latitudes of $14^{0}$ $54^{\prime}$ and $16^{\circ} 18^{\prime}$ and eastern longitudes of $76^{\circ} 58^{\prime}$ and $78^{\circ}$ $25^{\prime}$, the district is bounded on the north by Tungabhadra and Krishna rivers as well as Mahaboob nagar district of Telangana, on south by Kadapa and Anantapur districts, on the west by Karnataka state and on the south by Prakasam district. Kurnool district comprises 3 Revenue divisions (Kurnool, Nandyala and Adoni) consisting of 54 Revenue mandals. The major rivers flowing in the distrct are Tungabhadra, Hundri, Krishna and Kunderu.The total area 
under forests is $7,86,412$ acres accounting for about $18 \%$ of total geographical area of the district. The major soils of the Kurnool district are hilly soils, deep red sandy soils, shallow red sandy soils. The net area sown is 8.69 lakh hectares which forms $49.26 \%$ to the total geographical area. The total cropped area is 10.04 lakh hectares. The general altitude of the district varies from $300 \mathrm{mts}$ to $600 \mathrm{mts}$ above mean sea level. Nallamalas and Erramalas are the two important mountain ranges in the district running parallel from north to south. According to 2011 census, Kurnool district has a total population of 40.47 lakhs. Predominantly Kurnool district is rural in character with 75 percent of population living in rural areas.

\section{Results \& Discussions:}

\section{Spatial Patterns of Horticultural Crops}

The area under total horticultural crops in Kurnool district amounts to 8.75 percent to the total cropped area with an hectarage of 89,366 hectares occupying fourth place after Bengal gram (21.2\%), Groundnut (17.52\%) and Paddy $(13.42 \%)$. The major heads which are grouped together as horticultural crops for the study are Spices \& condiments, vegetable crops and fruit crops. With regard to total horticultural crops, very high concentration $(>20 \%)$ is found in C.Belagal (27.34\%) and Mahanandi (24.34\%) followed by high concentration (15-20\%) in Orvakal (19.57\%), Kodumur (18.88\%) and Kurnool (15.86\%) mandals. In about 12 mandals, moderate concentration (10-15\%), in 16 mandals, low concentration $(5-10 \%)$ and in 20 mandals very low $(<5 \%)$ concentration of Horticultural crops to the total cropped area is registered. As Srisailam mandal is composed of hilly terrain and natural vegetation, cultivation of crops is absent here (Fig -1).

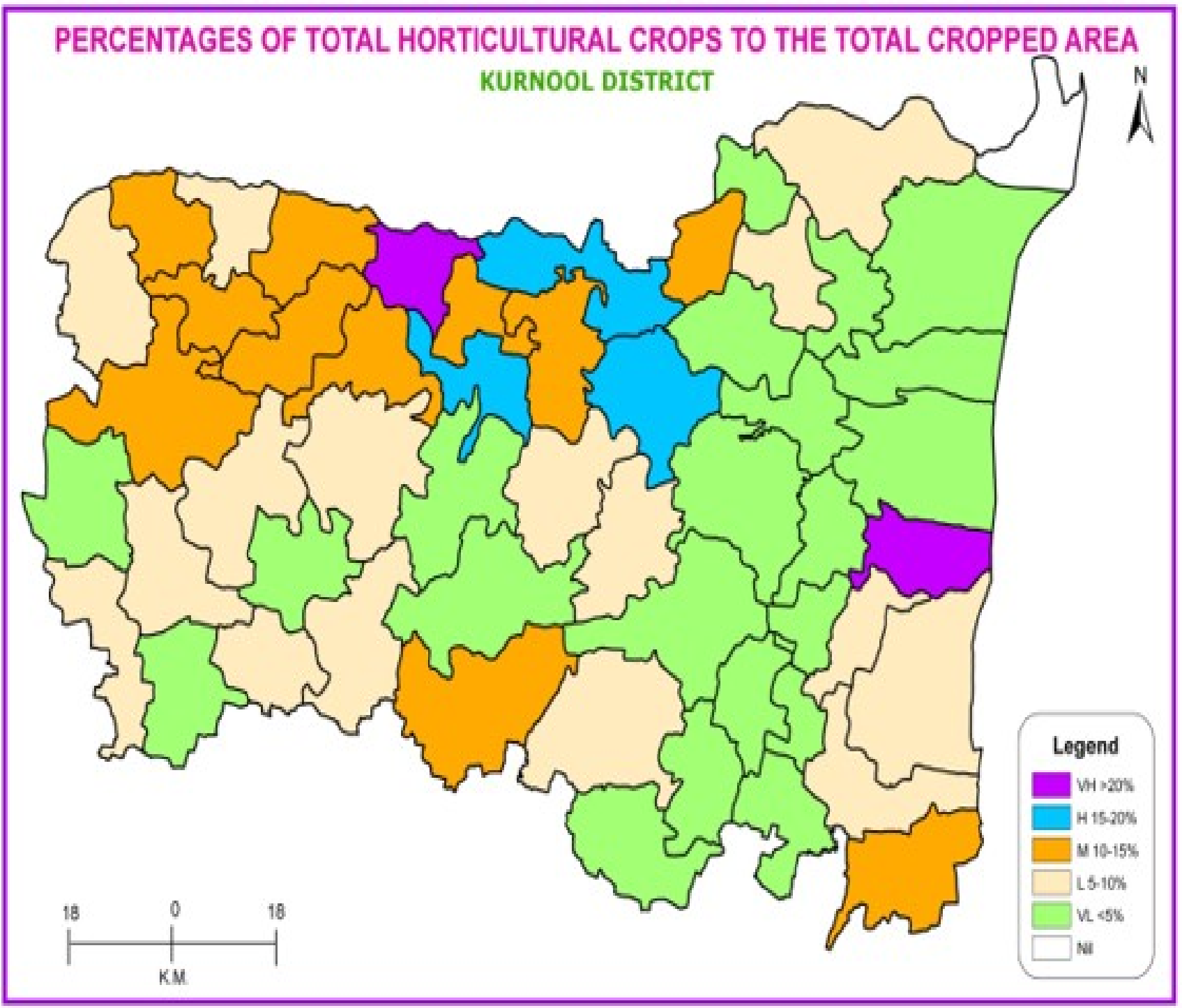

Fig:1 
International Journal of Trend in Scientific Research and Development (IJTSRD) @ www.ijtsrd.com eISSN: 2456-6470

TABLE-1

Percentages of Total spices \& condiments, Total vegetables and Total fruit cropped area to the total horticultural cropped area-Kurnool District,2010-11

\begin{tabular}{|c|c|c|c|c|}
\hline \multirow[b]{2}{*}{ S.NO } & \multirow[b]{2}{*}{ NAME OF THE MANDAL } & \multicolumn{3}{|c|}{ PERCENTAGE TO THE TOTAL HORTICULTURAL CROPPED AREA } \\
\hline & & $\begin{array}{c}\text { SPICES \& } \\
\text { CONDIMENTS }\end{array}$ & VEGETABLES & FRUITS \\
\hline 1 & MANTRALAYAM & 47.03 & 48.60 & 4.35 \\
\hline 2 & KOSIGI & 64.20 & 34.51 & 1.27 \\
\hline 3 & KOWTHALAM & 89.40 & 8.68 & 1.91 \\
\hline 4 & PEDDA KADUBUR & 67.76 & 31.30 & 0.93 \\
\hline 5 & YEMMIGANUR & 65.37 & 31.10 & 3.53 \\
\hline 6 & NANDAVARAM & 85.87 & 13.48 & 6.29 \\
\hline 7 & C.BELAGAL & 49.98 & 45.52 & 4.49 \\
\hline 8 & GUDUR & 48.03 & 39.98 & 11.97 \\
\hline 9 & KALLUR & 36.70 & 45.52 & 11.92 \\
\hline 10 & KURNOOL & 42.91 & 53.19 & 3.89 \\
\hline 11 & NANDIKOTKUR & 36.18 & 40.95 & 22.86 \\
\hline 12 & PAGIDYALA & 54.90 & 19.60 & 25.49 \\
\hline 13 & JUPADU BUNGALOW & 23.24 & 67.40 & 9.35 \\
\hline 14 & KOTHAPALLE & 25.16 & 61.14 & 13.69 \\
\hline 15 & SRISAILAM & 0 & 0 & 0 \\
\hline 16 & ATMAKUR & 14.62 & 12.86 & 72.51 \\
\hline 17 & PAMULAPADU & $74.56 \mathrm{~mm}$ & 17.55 & 7.88 \\
\hline 18 & MIDTHUR & 63.54 & 25.13 & 11.32 \\
\hline 19 & ORVAKAL & 21.67 tenthfic & 47.14 & 31.17 \\
\hline 20 & KODUMUR & 49.35 & 42.88 & 7.76 \\
\hline 21 & GONEGANDLA & 49.18 & 47.65 & 3.16 \\
\hline 22 & ADONI & 56.80 & 41.55 & 1.64 \\
\hline 23 & HOLAGUNDA & 76.19 & 8.60 & 15.20 \\
\hline 24 & HALAHARVI & 92.48 & 6.15 & 1.36 \\
\hline 25 & ALUR & or 73.49 scien & TIC & 0.85 \\
\hline 26 & ASPARI & R46.76 rch and & 52.90 & 0.33 \\
\hline 27 & DEVANAKONDA & 67.46 onment & 81.06 & 11.89 \\
\hline 28 & KRISHNAGIRI & 42.04 & 26.53 & 31.42 \\
\hline 29 & VELDURTHI & IS 24.21456-6470 & 39.66 & 36.11 \\
\hline 30 & BETHAMCHERLA & 20.19 & 51.57 & 28.23 \\
\hline 31 & PANYAM & $8,39.97$ & 15.47 & 44.54 \\
\hline 32 & GADIVEMULA & $67.05-7$ & 17.21 & 15.72 \\
\hline 33 & VELGODE & 61.15 & 17.74 & 21.10 \\
\hline 34 & BANDI ATMAKUR & $9.94 \cup \cup$ & $8 . .38$ & 81.67 \\
\hline 35 & NANDYAL & 65.12 & 13.35 & 21.52 \\
\hline 36 & MAHANANDI & 19.15 & 1.40 & 79.72 \\
\hline 37 & SIRVEL & 41.86 & 49.90 & 8.22 \\
\hline 38 & GOSPADU & 37.93 & 58.27 & 0.37 \\
\hline 39 & BANAGANAPALLE & 38.11 & 16.98 & 44.90 \\
\hline 40 & DHONE & 4.27 & 25.86 & 69.85 \\
\hline 41 & PATTIKONDA & 6.88 & 90.47 & 2.64 \\
\hline 42 & CHIPPAGIRI & 83.01 & 13.04 & 3.94 \\
\hline 43 & MADDIKERA ( EAST) & 60.87 & 34.41 & 4.70 \\
\hline 44 & TUGGALI & 24.93 & 63.23 & 11.82 \\
\hline 45 & PEAPALLY & 3.41 & 48.03 & 48.54 \\
\hline 46 & OWK & 81.87 & 15.86 & 2.26 \\
\hline 47 & KOILKUNTLA & 28.97 & 38.78 & 32.24 \\
\hline 48 & RUDRAVARAM & 43.89 & 29.45 & 26.64 \\
\hline 49 & ALLAGADDA & 22.51 & 53.35 & 24.13 \\
\hline 50 & DORNIPADU & 7.40 & 88.14 & 4.44 \\
\hline 51 & SANJAMALA & 57.02 & 29.82 & 13.15 \\
\hline 52 & KOLIMIGUNDLA & 64.44 & 9.87 & 25.67 \\
\hline 53 & UYYALAWADA & 39.73 & 8.48 & 51.78 \\
\hline 54 & CHAGALAMARRI & 22.36 & 40.84 & 36.79 \\
\hline & Total District & 47.38 & 36.49 & 16.13 \\
\hline
\end{tabular}




\section{Spatial Distribution of Vegetable crops}

In Kurnool district, the total vegetable crops occupy about 32,611 hectares of area accounting for 3.19 percent to the total cropped area and 36.49 percent of area to the total horticultural cropped area. The major vegetable crops cultivated in the study area gourds, Bhendi, Beans, Brinjal, carrot, Tomato, green chillies and green leafy vegetables. Very high concentration (>80\%) of vegetable crops to the total horticultural cropped area is noticed in Pattikonda (90.47\%), Dornipadu (88.14\%) and Devanakonda (81.06\%) followed by high concentration (60-80\%) in 3 mandals such as Jupadu Bangalow (67.4\%), Tuggali (63.24\%) and Kothapalle (61.15\%). Moderate concentration (40-60\%) of vegetable crops is observed in 15 mandals, low (20$40 \%)$ in 13 mandals and very low (<20\%) in 19 mandals of the district (Table - 1 ).

\section{Tomatoes}

With regard to individual crop concentration of vegetable crops, Tomatoes occupying maximum share of area with 5.89 percent to the total horticultural cropped area and 30.38 percent to the total vegetable cropped area accounting about 5,015 hectares of land. Highest percentage of area is found in Pattikonda (35.54\%) followed by Tuggali (33.02\%), Peapully (31.31\%) and Aspari (25.39\%) mandals. Tomato crop is completely absent in Mantralayam, Kowthalam, Pedda Kadubur, Jupadu Bangalow, Kothapalle, Srisailam, Atmakur, Bandi Atmakur, Nandyal, Mahanandi, Rudravaram, Allagadda, Dornipadu, Sanjamala, Kolimigundla and Chagalamarri mandals (Table -2).

\section{Beans}

Beans is the second important crop among all vegetable crops cultivated in Kurnool district, occupying about 3,414 hectares of land with a percentage share of 4.01 to the total horticultural cropped area and 20.47 percent to the total vegetable cropped area. Kodumur mandal topping the list in Beans cultivation with a maximum percentage of 31.16 followed by Bethamcherla (16.91\%), Pagidyala (16.79\%) and Midthur (14.5\%). The crop is completely absent in 21 mandals of the district (Table -2)

TABLE-2

Percentages of individual vegetable crops to the total horticultural cropped area-Kurnool District, 2010-11

\begin{tabular}{|c|c|c|c|c|c|c|c|c|c|}
\hline \multirow{2}{*}{$\begin{array}{l}\text { S. } \\
\text { No }\end{array}$} & \multirow{2}{*}{$\begin{array}{c}\text { Name of the } \\
\text { Mandal }\end{array}$} & \multicolumn{8}{|c|}{ Percentage To The Total Horticultural Cropped Area } \\
\hline & & Tomata & Beans & Bhendi & $\begin{array}{l}\text { Green } \\
\text { Chilles } \\
\end{array}$ & Brinjal & Gourds & $\begin{array}{c}\text { Green Leaf } \\
\text { Vegeble }\end{array}$ & Carrot \\
\hline 1 & MANTRALAYAM & 0.00 & 0.00 & 0.25 & 0.00 & 0.00 & 0.00 & 0.00 & 0.00 \\
\hline 2 & KOSIGI & 0.23 & 0.00 & 0.07 & 0.00 & 0.03 & 0.00 & 0.07 & 0.00 \\
\hline 3 & KOWTHALAM & 0.00 & 0.00 & 0.00 & 0.00 & 0.00 & 0.00 & 0.00 & 0.00 \\
\hline 4 & PEDDA KADUBUR & 0.00 & 1.35 & 0.00 & n 0.57 thic & 0.00 & 0.15 & 0.00 & 0.00 \\
\hline 5 & YEMMIGANUR & 1.12 & 2.87 & $0.45 \mathrm{e}$ & rch 2.83 & 0.70 & 0.24 & 0.00 & 0.00 \\
\hline 6 & NANDAVARAM & 0.47 & 0.00 & 0.12 & 0.94 & 0.55 & 0.08 & 0.00 & 0.00 \\
\hline 7 & C.BELAGAL & 0.66 & 1.23 & 0.18 & 3.88 & 0.24 & 0.09 & 0.00 & 2.04 \\
\hline 8 & GUDUR & 2.66 & 28.6 & 2.47 & 456.3 .61 & 2.03 & 1.84 & 0.00 & 1.84 \\
\hline 9 & KALLUR & 5.52 & 7.73 & 0.77 & 1.88 & 1.47 & 0.90 & 1.71 & 0.20 \\
\hline 10 & KURNOOL & 3.99 & 1.22 & 0.61 & 0.68 & 0.75 & 0.86 & 0.61 & 0.07 \\
\hline 11 & NANDIKOTKUR & 1.25 & 0.00 & 0.48 & 12.63 & 0.13 & 0.90 & 0.00 & 0.00 \\
\hline 12 & PAGIDYALA & 4.58 & 16.79 & 0.76 & 24.42 & 1.52 & 0.76 & 0.00 & 0.00 \\
\hline 13 & JUPADU BUNGALOW & 0.00 & 6.17 & 0.00 & 22.55 & 0.00 & 9.46 & 0.00 & 0.00 \\
\hline 14 & KOTHAPALLE & 0.00 & 0.00 & 0.00 & 7.86 & 0.00 & 0.32 & 0.00 & 0.00 \\
\hline 15 & SRISAILAM & 0.00 & 0.00 & 0.00 & 0.00 & 0.00 & 0.00 & 0.00 & 0.00 \\
\hline 16 & ATMAKUR & 0.00 & 9.49 & 0.00 & 4.74 & 0.00 & 4.74 & 0.00 & 0.00 \\
\hline 17 & PAMULAPADU & 1.89 & 0.00 & 3.93 & 1.08 & 0.00 & 0.00 & 0.00 & 0.00 \\
\hline 18 & MIDTHUR & 2.63 & 14.5 & 1.40 & 0.00 & 4.85 & 0.98 & 0.00 & 0.00 \\
\hline 19 & ORVAKAL & 6.84 & 9.11 & 3.58 & 9.48 & 1.35 & 1.22 & 0.41 & 0.09 \\
\hline 20 & KODUMUR & 2.39 & 31.16 & 2.12 & 1.35 & 0.82 & 2.64 & 0.06 & 0.33 \\
\hline 21 & GONEGANDLA & 2.45 & 1.30 & 0.43 & 1.66 & 0.31 & 0.91 & 0.00 & 0.03 \\
\hline 22 & ADONI & 9.15 & 0.65 & 4.45 & 0.13 & 8.32 & 2.62 & 2.96 & 0.00 \\
\hline 23 & HOLAGUNDA & 0.90 & 0.47 & 0.14 & 0.00 & 0.33 & 0.28 & 1.09 & 0.00 \\
\hline 24 & HALAHARVI & 1.41 & 0.00 & 0.00 & 0.00 & 0.00 & 0.00 & 0.00 & 0.00 \\
\hline 25 & ALUR & 1.56 & 1.10 & 0.17 & 0.00 & 0.23 & 0.34 & 0.05 & 0.00 \\
\hline 26 & ASPARI & 25.39 & 7.03 & 1.01 & 1.46 & 4.44 & 0.73 & 0.00 & 0.11 \\
\hline 27 & DEVANAKONDA & 13.02 & 2.88 & 1.19 & 1.42 & 1.19 & 0.82 & 0.00 & 0.09 \\
\hline 28 & KRISHNAGIRI & 6.41 & 1.73 & 0.95 & 4.50 & 0.78 & 0.17 & 0.00 & 0.17 \\
\hline 29 & VELDURTHI & 7.92 & 4.37 & 0.83 & 8.62 & 0.77 & 0.90 & 0.00 & 0.00 \\
\hline 30 & BETHAMCHERLA & 8.89 & 16.91 & 0.63 & 11.99 & 5.40 & 0.39 & 0.00 & 0.15 \\
\hline 31 & PANYAM & 0.42 & 2.32 & 4.64 & 1.16 & 1.37 & 0.63 & 0.00 & 0.00 \\
\hline 32 & GADIVEMULA & 2.83 & 0.00 & 43.86 & 55.18 & 0.94 & 1.41 & 0.00 & 0.00 \\
\hline 33 & VELGODE & 0.12 & 1.03 & 0.51 & 3.61 & 2.19 & 1.03 & 0.00 & 0.00 \\
\hline 34 & BANDI ATMAKUR & 0.00 & 0.00 & 4.04 & 0.00 & 0.00 & 0.38 & 1.15 & 0.00 \\
\hline 35 & NANDYAL & 0.00 & 0.00 & 0.55 & 2.31 & 1.21 & 3.19 & 1.32 & 0.00 \\
\hline
\end{tabular}


International Journal of Trend in Scientific Research and Development (IJTSRD) @ www.ijtsrd.com eISSN: 2456-6470

\begin{tabular}{|l|c|c|c|c|c|c|c|c|c|}
\hline 36 & MAHANANDI & 0.00 & 0.00 & 0.00 & 0.00 & 0.00 & 0.08 & 0.00 & 0.00 \\
\hline 37 & SIRVEL & 1.21 & 1.58 & 18.87 & 0.73 & 0.00 & 0.12 & 0.00 & 0.00 \\
\hline 38 & GOSPADU & 0.53 & 0.00 & 14.20 & 0.00 & 0.53 & 0.00 & 0.00 & 0.00 \\
\hline 39 & BANAGANAPALLE & 1.04 & 0.00 & 4.18 & 0.00 & 1.04 & 0.00 & 0.00 & 0.00 \\
\hline 40 & DHONE & 13.89 & 5.50 & 0.25 & 2.17 & 2.63 & 0.32 & 0.00 & 0.13 \\
\hline 41 & PATTIKONDA & 35.54 & 1.62 & 0.58 & 0.46 & 0.69 & 0.34 & 0.00 & 0.00 \\
\hline 42 & CHIPPAGIRI & 1.79 & 0.00 & 0.00 & 0.00 & 0.00 & 0.08 & 0.04 & 0.00 \\
\hline 43 & MADDIKERA(EAST) & 8.45 & 1.08 & 0.00 & 0.00 & 0.10 & 0.21 & 1.30 & 0.00 \\
\hline 44 & TUGGALI & 33.02 & 4.33 & 2.75 & 1.50 & 3.66 & 1.08 & 0.00 & 0.00 \\
\hline 45 & PEAPALLY & 31.31 & 1.12 & 0.40 & 2.39 & 0.80 & 0.25 & 0.05 & 0.43 \\
\hline 46 & OWK & 0.36 & 0.00 & 15.37 & 3.79 & 0.36 & 0.00 & 0.00 & 0.00 \\
\hline 47 & KOILKUNTLA & 0.93 & 2.33 & 21.02 & 0.00 & 2.33 & 0.46 & 0.00 & 0.00 \\
\hline 48 & RUDRAVARAM & 0.00 & 0.00 & 21.96 & 0.51 & 0.00 & 0.19 & 0.00 & 0.00 \\
\hline 49 & ALLAGADDA & 0.00 & 0.00 & 24.63 & 0.00 & 0.00 & 0.47 & 0.00 & 0.00 \\
\hline 50 & DORNIPADU & 0.00 & 0.00 & 35.84 & 0.00 & 0.00 & 0.00 & 0.00 & 0.00 \\
\hline 51 & SANJAMALA & 0.00 & 1.79 & 1.12 & 0.89 & 0.89 & 0.22 & 0.00 & 0.00 \\
\hline 52 & KOLIMIGUNDLA & 0.00 & 1.27 & 0.73 & 1.46 & 3.83 & 0.36 & 0.00 & 0.00 \\
\hline 53 & UYYALAWADA & 0.27 & 0.00 & 15.67 & 0.00 & 0.00 & 0.00 & 0.00 & 0.00 \\
\hline 54 & CHAGALAMARRI & 0.00 & 0.50 & 9.62 & 0.00 & 0.41 & 0.27 & 0.00 & 0.00 \\
\hline \multicolumn{2}{r}{ Kurnool District } & $\mathbf{5 . 8 9}$ & $\mathbf{4 . 0 1}$ & $\mathbf{2 . 6 3}$ & $\mathbf{2 . 3}$ & $\mathbf{1 . 1 7}$ & $\mathbf{0 . 7 3}$ & $\mathbf{0 . 2 3}$ & $\mathbf{0 . 1 9}$ \\
\hline
\end{tabular}

\section{Bhendi}

It is the third most important crop among all vegetable crops of Kurnool district. Bhendi occupying about 2,241 hectares of land accounting for 2.63 percent of area to the total horticultural cropped area and 12.87 percent to the total vegetable cropped area. Gadivemula mandal having maximum share of land (43.86\%) under bhendi cultivation to the total horticultural cropped area followed by Dornipadu (35.84\%), Allagadda (24.63\%), Rudravaram (21.96\%), Koilkuntla (21.02\%) and others. In 9 mandals, Bhendi crop is (Table -2) not cultivated during the study period.

\section{Green Chillies}

In the study region, about 2.3 percent of area is under green chillies to the total horticultural cropped area and $12 \%$ to the total vegetable cropped area with actual hectarage of 1,958 hectares in Kurnool district. Maximum area under green chillies is registered in Gadivemula mandal (55.18\%). The other mandals with higher concentration of green chillies are Pagidyala (24.42\%) and Jupadu Bangalow $(22.55 \%)$. Green chillies is not gained ground in about 19 mandals of the district (Table -2).

\section{Brinjal}

Brinjal is an another important vegetable crop in Kurnool district, occupying 1.17 percent of area to the total horticultural cropped area and 6.07 percent to the total vegetable cropped area with an hectarage of 1,002 hectares. Maximum percentage of area is reported in Adoni mandal (8.32\%) followed by Midthur (4.85\%) and Aspari (4.44\%). In about 17 mandals, Brinjal crop has not occupied any amount of land (Table -2).

\section{Gourds}

Gourds are of different kinds such as Ridge gourd, snake gourd, bottle gourd, bitter gourd etc. Gourds are occupying an area of 0.73 percent to the total horticultural cropped area and 2.92 percent to the total vegetable cropped area consisting of 628 hectares. Highest concentration is observed in Jupadu Bangalow (9.46\%) followed by Atmakur $(4.74 \%)$ mandal. Eleven mandals of the study area is not having even an inch of land under gourds cultivation (Table 2).

\section{Green leafy vegetables}

Green leafy vegetables occupying very little area with only 0.23 percent to the total horticultural cropped area amounting to 196 hectares of land. In only 13 mandals, green leafy vegetables are cultivated in Kurnool district during the study period with a maximum of area in Adoni (2.96\%) followed by Kallur (1.71\%), Nandyal (1.32\%), Maddikera (1.30\%), Bandi Atmakur (1.15\%) and Holagunda (1.09\%) (Table -2).

\section{Carrot}

Very negligible amount of area is under carrot cultivation in the district with only 0.17 percent to the total horticultural cropped area and 0.90 percent to the total vegetable cropped area occupying about 148 hectares of land. Carrot gained ground only in 13 mandals and in rest of the 41 mandals this crop is absent completely. Spatially, maximum percentage of area is observed in C.Belagal mandal (2.04\%) followed by Gudur (1.84\%) (Table-2).

\section{Conclusion:}

At present Vegetable farming became highly profitable than growing paddy and wheat. There is enormous gap in demand and supply of vegetables in India. As vegetables are quickly perishable unlike paddy and wheat, farmers have to choose longer keeping quality vegetables for growing to increase their profitability. Vegetables such as cucurbits, beets, tomato, onion, carrots and cabbage are highly remunerative compared to field crops. So, by balancing all the other factors, farmers have to go ahead with the vegetable farming, especially organic vegetables.

\section{References:}

[1] apeda.gov.in/apedawebsite/sixhead_product/FFV.htm

[2] https://pdfs.semanticscholar.org

[3] Kumar, S., PK Joshi, S. Pal (2004), Impact of vegetable research in India, krishi.icar.gov.in

[4] Singh, M. K. (1982). Production and marketing of vegetables around Hyderabad. M.Sc (Agri. Thesis APAU, Hyderabad.

[5] Subramanyam,K.V. (1989). Economics of cultivation of horticulture crops in South India.Technical Bulletin No.7 IIHR, Banglore p.44-61

[6] https:www.indiaagronet.com 